\title{
PERSEPSI DAN SIKAP MASYARAKAT TERHADAP WISATA SYARIAH (HALAL TOURISM) DI PULAU SANTEN KABUPATEN BANYUWANGI
}

\author{
Achmad Fawaid dan Juzrotul Khotimah
}

\author{
Universitas Nurul Jadid \\ fawaidachmad@gmail.com,muhfa.revolver@gmail.com
}

Diterima 17 Februari 2019 | Direview 09 April 2019 |Diterbitkan 25 Juni 2019

\begin{abstract}
Sharia / halal tourism tourism is a trend and golden opportunity for the region. Banyuwangi as one of the regions that has natural resources such as coastal, sea, and small islands trying to develop the tourism sector located in Santen Island, Karangrejo Banywwangi Village with sharia tourism forms. The aim of the research is to find out how the perceptions and attitudes of the community towards the existence of sharia tourism (halal tourism) in Banyuwangi Regency. The research methods used in this study are interviews, documentation and observation. While the analysis is interactive models consisting of several components such as: data reduction, presentation data, drawing and testing data. The finding of this study is the application of the concept of Islamic tourism on Santen Island are still not optimal. The community has a positive perception with a value of 75\%, a positive attitude with an $80 \%$ value and positive participation with a value of $85 \%$ of visitors, the results of the Islamic travel concept of $70 \%$ of visitors who consider the location clean and 30\% of visitors consider the location unclean, visitors say facilities which is quite adequate on Santen Island with a value of 65\% of visitors assuming that the separation of men and women has not been carried out in accordance with the concept of Islamic tourism. While the economic impact has experienced an increase in the local economy and reduced unemployment for the people on the island of Santen.
\end{abstract}

Keywords: Perception and Attitude, Syariah Tourism, Santen Island

\begin{abstract}
Abstrak
Wisata syariah/halal tourism menjadi tren dan golden opportunity bagi daerah. Banyuwangi sebagai salah satu daerah yang memiliki sumber daya alam seperti: pesisir, laut, dan pulau kecil mencoba untuk mengembangkan sektor pariwisata yang berada Pulau
\end{abstract}


Santen Kelurahan Karangrejo Banyuwangi dengan bentuk wisata syariah. Tujuan penelitian ini adalah untuk mengetahui bagaimana persepsi dan sikap masyarakat terhadap adanya wisata syariah (halal tourism) di Kabupaten Banyuwangi. Beberapa metode penelitian yang digunakan diantaranya adalah wawancara, dokumentasi dan observasi. Sedangkan analisis yang dapat digunakan diantaranya adalah model interaktif yang terdiri dari beberapa komponen seperti: reduksi data, data presentasi, menggambardan menguji data. Temuan dalam penelitian ini termasuk penerapan konsep pariwisata Islam di Pulau Santen masih belum optimal. Masyarakat memiliki persepsi positif dengan nilai $75 \%$, sikap positif dengan nilai $80 \%$ dan partisipasi positif dengan nilai $85 \%$ dari pengunjung, hasil konsep perjalanan syariah sebesar $70 \%$ dari pengunjung yang menganggap lokasi bersih dan 30\% pengunjung menganggap lokasi tidak bersih, pengunjung mengatakan fasilitas yang ada cukup memadai di Pulau Santen dengan nilai 65\% para pengunjung menganggap bahwa pemisahan laki-laki dan perempuan belum terlaksana sesuai dengan konsep pariwisata islami, sedangkan dari dampak ekonomi telah mengalami peningkatan ekonomi lokal dan mengurangi pengangguran bagi masyarakat di Pulau Santen.

Kata Kunci: Persepsi dan Sikap,Wisata Syariah, Pulau Santen

\section{Pendahuluan}

Wisata syariah di Indonesia masih sangat minim keberadaannya. Di Provinsi Jawa Timur saja hanya ada di Kabupaten Banyuwangi yang pemerintahannya melakukan pengembangan terhadap wisata yang berkonsep syariah tersebut, namun kebanyakan masyarakat masih belum sepenuhnya mengetahui adanya wisata yang berkonsep syariah tersebut. Justru wisata tersebut terdengar aneh bagi masyarakat awam wisata yang berkonsep Syariah atau Halal Tourism adalah salah satu bentuk pariwisata yang khusus untuk para wisatawan muslim ataupun non-muslim yang didalam konsep tersebut mematuhi aturan syariah adanya wisata halal kini menjadi familiar dikalangan wisatawan muslim karena itu di berbagai daerah di Nusantara semakin menggencarkan pembaharuan konsep pariwisata tidak mau kalah dengan adanya wisata syariah, Aceh dan Lombok juga mencoba untuk meniru konsep tersebut. 
Wisata syariah yang ada di Banyuwangi terletak di ujung paling timur Pulau Jawa yang berbatasan dengan Kabupaten Situbondo di ujung utara, Selat Bali di ujung timur, Samudra Hindia di ujung selatan, serta dua Kabupaten lainnya yaitu Kabupaten Jember dan Kabupaten Bondowoso yang terletak dibagian barat. Kabupaten Banyuwangi merupakan Kabupaten terluas di Jawa Timur, bahkan bisa dibilang terluas di Jawa, luas Kabupaten Banyuwangi mencapai 5.782,50 Km2. Kabupaten Banyuwangi dikelilingi oleh berbagai macam kekayaan alam yang beragam mulai daripegunungan hingga laut lepas. ${ }^{1}$

Sebuah inovasi terbaru wisata syariah di Bayuwangi datang dari Pemerintah Daerah dengan menjadikan Pulau Santen di Kelurahan Karangrejo menjadi wisata yang berbasis Syariah. Daerah bagian timur pulau Jawa ini terbilang sangat serius untuk mengembangkan potensi wisatanya, hal tersebut dilihat dari munculnya beberapa destinasi wisata baru yang bermunculan dari waktu kewaktu seperti yang booming yaitu jembatan warna-warni sungai kalilo yang mana dari kreatifitas masyarakat Banyuwangi mampu menyulap sebuah sungai dan perkampungan yang dulunya terkesan kumuh menjadi berwarna bersih dan indah untuk dipandang bahkan menjadi objek wisata yang banyak diminati wisatawan untuk bersantai maupun sekedar berfoto. Di jembatan sungai kalilo tersebut, pengunjung tidak hanya bisa untuk bersantai dan berfoto saja baru-baru ini Kabupaten Banyuwangi juga mengenalkan destinasi wisata baru yaitu wisata pulau santen dengan menyuguhkan pesona keindahan pantai yang berkonsep syari'ah. ${ }^{2}$

Meningkatnya pertumbuhan ekonomi perdagangan dan pariwisata tidak lepas dari posisi strategis yang ada di Kabupaten Banyuwangi dimana lokasi tersebut berdekatan dengan Pulau Bali, yang menyuguhkan berbagai jenis wisata yang ada di Banyuwangi seperti wisata bahari, wahana wisata dan wisata buatan yang dikelola oleh pemerintah Kabupaten Banyuwangi. ${ }^{3}$ Selain itu akses menuju wisata syariah mudah dijangkau oleh wisatawan karena jalan utama menuju lokasi tersebut sudah di aspal.

Keanekaragaman potensi alam, kekayaan seni, budaya, dan adat tradisi Banyuwangi merupakan sebuah mahkota yang harus dipelihara dan

\footnotetext{
1 M Indra, "Analisis Pengembangan Pulau Santen Dengan Konsep Wisata Syariah," Jurnal Administrasi Bisnis (JAB) 55, no. 1 (2018): 144-50.

${ }^{2}$ Khoirul Hadi al-Asy Ari, M, "Kajian Potensi Dan Strategi Pengembangan Wisata Pantai Syariah," Jurnal MD 3, n.d.

3 Badan Koordinasi Penanaman Modal (BKPM), Potensi Dan Peluang Investasi Kabupaten Banyuwangi (Jakarta: PT Buanatama DimensiConsultants, 2013).
} 
ditunjukkan kepada dunia luar. Dengan begitu potensi tersebut dapat bermanfaat baik untuk masyarakat maupun pemerintah dalam meningkatkan pendapatan perekonomian asli daerah aset tersebut menjadi point penting dalam pembangunan terutama di sektor pariwisata yang harus diangkat ke kancah nasional maupun internasional. ${ }^{4}$

Langkah ini memiliki potensi yang sangat besar untuk menarik wisatawan lokal dan asing karena Indonesia memiliki peluang besar untuk menarik turis mancanegara terutama wisatawan Muslim selain itu tren halal tourism terus tumbuh dan harus direspons untuk pengembangan pariwisata daerah. Di sisi lain, wisata jenis ini diyakini akan memberi warna baru bagi pariwisata Indonesia khususnya Kabupaten Banyuwangi yang dikenal dengan sebutan the sunrise of java karena menjadi pembeda antara pariwisata Banyuwangi dengan daerah lain. ${ }^{5}$

Untuk menangkap peluang kunjungan wisatawan dari kawasan Banyuwangi dan kawasan lainya yang berpenduduk mayoritas islam salah satu pantai yang berada di Banyuwangi kerap kali di sebut dengan sebutan pulau santen dijadikan tempat wisata dimana wisata pulau santen merupakan gebrakan yang dilakukan Pemerintah Kabupaten (Pemkab) Banyuwangi. Sebelum launching pihak Pemkab setempat menginginkan adanya diferensiasi dan segmentasi baru dalam dunia pariwisata Banyuwangi. Setelah melalui musyawarah yang matang oleh Bupati Banyuwangi dengan Pemkab Banyuwangi maka muncullah sebuah ide konsep wisata Pulau Santen (pantai syari'ah) wisata tersebut merupakan suatu wisata yang banyak digemari oleh masyarakat pada umumnya semenjak terkonsep sebagai destinasi wisata halal pertama di Banyuwangi.

Setiap daerah di Indonesia memiliki laut yang sangat luas oleh karena itu Indonesia mempunyai potensi untuk mengembangkan wisata syariah salah satu daerah yang mengembangkan wisata syariah adalah Kabupaten Banyuwangi di tahun 2017. Wisata syariah di Banyuwangi kerap kali di sebut dengan Pulau Santen. ${ }^{6}$

\footnotetext{
${ }^{4}$ Nur, Siti Khayisatu Zahro, "Pengembangan Sector Pariwisata Melalui Program Festival Halal Kuliner,” Jurnal Et-Tijarie 5 (n.d.): 2.

${ }^{5}$ Khoirul Hadi al-Asy Ari, M, "Kajian Potensi Dan Strategi Pengembangan Wisata Pantai Syariah."

${ }^{6}$ Susanti, Nawal Ika, "Respon Masyarakat Terhadap Pantai Syariah Pulau Santen Di Kelurahan Karangrejo Banyuwangi," Jurnal Istiqro, 1, 4 (n.d.).
} 
Sejalan dengan hal tersebut pariwisata syari'ah memiliki potensi yang besar untuk dikembangkan apalagi di Kota Banyuwangi yang terkenal dengan indahnya pemandangan laut para wisatawan biasa menyebutnya dengan sebutan the sunrise of java. Esensi wisata syari'ah terletak pada usaha menyingkirkan segala hal yang dapat membahayakan bagi manusia dan mendekatkan manusia kepada hal yang akan membawa manfaat bagi dirinya maupun lingkungan hal ini menarik banyak wisatawan asing terutama untuk kalangan kaum muslim namun hal tersebut tidak terbatas pada kaum muslim saja penganut agama lain juga tertarik dengan adanya konsep wisata syari'ah.

Minat terhadap wisata syari'ah harus direspons dan turut mengembangan usaha wisata syari'ah di Indonesia sehingga dapat turut menggerakkan perekonomian nasional sayangnya saat ini wisata syari'ah di Indonesia sendiri masih digarap setengah-setengah terbukti baru sebatas pengembangan wisata konvensional saja seandainya wisata syariah di garap dengan baik pasti akan menjadi aset tertinggi bagi perekonomian masyarakat ataupun perekonomian daerah dengan banyaknya wisatawan manca negara yang tertarik seperti apakah konsep wisata syariah tersebut, bisa berpotensi mendongkrak cadangan devisa negara bagi pasar wisatawan Muslim mancanegara.

Penelitian ini sangat berbeda dengan penelitian terdahulu dimana penelitian yang sekarang memfokuskan pada presepsi dan sikap masyarakat terhadap adanya wisata syariah (halal tourism) di Kabupaten Banyuwangi dalam telaah pustaka ini akan di lakukan pelacakan terhadap penelitian terdahulu yang relavan dengan presepsi dan sikap masyarakat terhadap adanya wisata syariah (halal tourism) di Kabupaten Banyuwangi. Adapun hasil dari pelacakan yang dilakukan oleh peneliti, penelitian terdahulu fokus pada:

Pertama, pengembangan wisata yang berupa pembangunan, pemeliharaan, dan pelestarian tanaman di Pulau Santen dimana Pulau Santen yang dulunya terkenal dengan pantai yang sangat kumuh dan saat ini masyarakat dituntut untuk menyumbangsihkan pemikiran untuk mengembangkan pelestarian tanaman seperti melakukan penanaman magrove di sekitar lokasi pantai.

Kedua, masyarakat Nusa Tenggara Barat memiliki persepsi yang baik terhadap rencana penerapan wisata halal didaerah tersebutsikap yang positif terhadap rencana penerapan wisata halal di daerah tersebut dan dari diagram kartesius diketahui bahwa hasil rencana penerapan wisata halal dipersepsikan dan disikapi sangat tinggi oleh masyarakat NTB dalam pengambil keputusan ini 
pemerintah NTB harus membuat kebijakan yang mempertahankan persepsi dan sikap itu tetap Baik dan Positif dengan membuat kebijakan yang konkrit terkait dengan implementasi pariwisata halalsehingga tidak sekedar pada tataran hukum atau peraturan daerah selain itu sosialisasi perlu dipercepat sehingga masyarakat paham bagaimana wisata halal tersebut akan diterapkan. ${ }^{7}$

Penelitian ini menggunakan pendekatan deskriptif yang dilakukan dengan cara mendeskripsikan segala sesuatu terkait dengan objek wisata, presepsi dan sikap terhadap adanya wisata syari'ah di Pulau Santen Banyuwangi. Peneliti melakukan observasi, wawancara dan dokumentasi untuk memberikan data serta pendapatnya terkait dengan objek wisata tersebut. Adapun lokasi penelitian adalah di Pulau Santen yang secara administratif terletak di Kelurahan Karangrejo Kabupaten Banyuwangi yang terdapat di sebelah timur pusat pemerintahan Banyuwangi sedangkan subjek penelitian terdiri dari dua jenis, yaitu subjek primer dan sekunder.

Subjek primer adalah mereka yang tergolong sebagai pelaku (orang) utama dan yang kedua adalah orang (asli) yang dijadikan penelitian sementara subjek sekunder adalah mereka yang hanya sebagai pendukung terhadap pelaku utama yang diteliti Subjek sekunder dipergunakan sebagai sumber data tambahan untuk memperkuat data yang dikemukakan subjek primer.

\section{Deskripsi Wisata Syariah Pulau Santen}

Wisata syariah (Pulau Santen) Banyuwangi yang diresmikan pada tanggal 2 Maret 2017 lalu oleh Bupati Banyuwangi Abdullah Azwar Anas menjadi pionir bagi wisata syari'ah yang ada di kota tersebut. Dengan hadirnya wisata ini menjadikan kota Banyuwangi mulai banyak dikenal di berbagai daerah bahkan wisatawan mancanegara. Pengangkatan konsep syari'ah menjadi keunikan tersendiri bagi pantai tersebut. Pada dasarnya tujuan utama pembentukan pariwisata yaitu untuk menarik wisatawan untuk datang, yang mana wisatawan itu dapat memberikan sumbangsih terhadap pendapatan daerah atau bahkan pendapatan negara. Diharapkan juga dapat meningkatkan perekonomian masyarakat sekitar tempat wisata. Dalam rangka menarik wisatawan untuk dating, maka setiap daerah harus memiliki obyek wisata yang dapat mempengaruhi wisatawan untuk berkunjung. Objek wisata menurut undang-undang Nomor 10 Tahun 2009 tentang kepariwisataan "Objek wisata

\footnotetext{
${ }^{7}$ Firdausia Hadi and M. Khoirul Hadi al-Asy Ari, "KAJIAN POTENSI DAN STRATEGI PENGEMBANGAN WISATA PANTAI SYARI'AH (Studi Di Pulau Santen Kabupaten Banyuwangi)," Jurnal Manajemen Dakwah 3, no. 2 (2017): 99-166.
} 
atau disebut daya tarik wisata adalah segala sesuatu yang memiliki keunikan, keindahan dan nilai yang berupa keanekaragaman kekayaan alam, budaya, dan basil buatan manusia yang menjadi sasaran atau tujuan kunjungan wisata".

Konsep tersebut digagas oleh Bupati Anas sebagai suatu peluang besar bagi kota Banyuwangi dengan melihat minat masyarakat akan hal yang berbau syari'ah pantai ini juga dibentuk dalam rangka menggali potensi serta membasmi pantai yang awal mulanya disebut pantai ma'siat dimana konsep halal tourism menurut shakiry adalah "The concept of sharia tourism is not limited to religious tourism, but it extend to all forms of tourist except those go against islamic values." Pulau Santen mengunakan konsep halal tourism dengan sistem-sistem nilai syari'ah yang dituangkan dalam wisata syariah diantara konsep-konsep tersebut adalah pemisahan tempat wisatawan yang berkunjung antara pengunjung perempuan dengan laki-laki. Khusus perempuan berada di sebelah kiri dan lakilaki disebelah kanan, hal ini juga diatur jelas menggunakan papan penunjuk yang tertulis "memberikan kebijakan bahwasanya makanan dan minuman yang dijual di tempat wisata harus halal". Wisata pantai Pulau Santen ini juga tidak hanya diperuntukkan untuk wisatawan Muslim saja namun juga wisatawan nonmuslim dengan syarat bahwa wisatawan tersebut dapat menghormati nilai-nilai Islam. ${ }^{8}$

Kabupaten Banyuwangi saat ini menjadi salah satu destinasi wisata favorit di Jawa Timur pengembangan potensi wisata, promosi wisata dan pembangunan infrastruktur di bidang pariwisata mampu menarik minat wisatawan baik dalam negeri maupun wisatawan asing untuk berkunjung ke Kabupaten Banyuwangi. Kabupaten Banyuwangi juga didukung oleh potensi wisata yang beragam mulai wisata alam sampai budaya yang khas serta letak geografis yang bersebelahan dengan Pulau Bali yang merupakan salah satu destinasi wisata dunia, sehigga memudahkan dalam melakukan promosi.

Berbagai promosi wisata dilakukan oleh Pemerintah Banyuwangi pada Tahun 2016 jumlah total kunjungan wisatawan ke Banyuwangi adalah sebanyak 3.126.602 wisatawan yang terdiri dari 3.054.576 wisatawan lokal dan 72.026 wisatawan asing, Peningkatan jumlah wisatawan yang datang pada tahun 2016 ini meningkat tajam dibandingkan tahun 2015 yang hanya sebanyak 1.742.230 wisatawan atau meningkat 79,45\% jika dilihat dari jumlah kunjungan wisatawan

\footnotetext{
8 M. Khoirul Hadi al-Asy Ari, "Kajian Potensi Dan Strategi Pengembangan Wisata Pantai Syariah.”
} 
dari 2010-2016 kondisi kunjungan wisatawan ke Banyuwangi memperlihatkan tren positif yang meningkat di bagian sektor wisata Kabupaten.'

Bupati Anas memberi target waktu sampai April 2017 agar semua fasilitas di Pulau Santen sudah terwujud dalam mewujudkan hal tersebut Bupati Anas menggunakan strategi yaitu dengan menggunakan model keroyokan yang melibatkan semua Satuan Kerja Perangkat Daerah (SKPD) Banyuwangi dan elemen masyarakat lainnya. ${ }^{10}$

Akan tetapi hingga bulan November 2018 ketika peneliti melakukan riset penelitian hanya beberapa fasilitas saja yang terpenuhi jaminan fasilitas halal yang sudah diterapkan di Pulau Santen antara lain makanan halal, tidak menjajakan alkohol, tempat bersuci lengkap dengan fasilitas tempat ibadah, serta fasilitas berkonsep pemisah antara laki-laki dan perempuan sedangkan pemberitahuan waktu jelang beribadah (adzan) masih belum ada. Pramuwisata di Pulau Santen juga masih belum mengenakan kerudung dan belum mengedepankan konsep islami karena jika ada wisatawan datang mereka belum memberikan salam sapa dengan ramah serta sopan dan santun yang belum di terapkan. Namun semua itu sudah menjadi perhatian bagi Pemkab Banyuwangi untuk selalu menjadikan wisata tersebut benar-benar islami sesuai dengan konsep awal dimana wisata tersebut bisa menjadi Wisata Syariah.

Sesuai dengan konsep slogan syariah yaitu "Kebersihan sebagian dari iman" untuk menjaga kelestarian, keindahan dan kebersihan kawasan Pulau Santen wisatawan diwajibkan membawa kantong plastik sebagai tempat sampah makanan yang dibawa namun hal ini masih belum tersosialisasikan dengan baik, karena masih banyak wisatawan yang tidak membawa kantong plastik sehingga kebersihan Pulau Santen tidak terjaga. Air bersih juga masih terbatas di Pulau Santen. ${ }^{11}$

Selain jaminan fasilitas halal yang harus terpenuhi beberapa peran dari SKPD dan elemen masyarakat yang sudah terealisasi diantaranya sebagai berikut: Pertama, Peran masyarakat dimana masyarakat setempat menjadi subjek pengembangan dan penataan Pulau Santen menjadi destinasi wisata baru yang masih belum optimal dalam pemberdayaan SDM masyarakat setempat. Kedua, TNI berperan aktif dalam berbagai program penataan ini karena tanah Pulau Santen ini milik TNI AD Peran TNI dalam berbagai program penataan Pulau

\footnotetext{
${ }^{9}$ M. Khoirul Hadi al-Asy Ari.

10 Susanti, Nawal Ika, "Respon Masyarakat Terhadap Pantai Syariah Pulau Santen Di Kelurahan Karangrejo Banyuwangi."

${ }^{11}$ Susanti, Nawal Ika.
} 
Santen ini sudah optimal meskipun masih ada miss komunikasi antara TNI dan SKPD yang terlibat dalam penataan Pulau Santen tersebut. Ketiga, Dinas PU (Pekerjaan Umum) berperan dalam penataan infrastruktur (jalan, jembatan, air bersih dan sejenisnya) jembatan yang menghubungkan Pulau Santen dan daerah Karangrejo sudah diperbaiki dan sudah bisa dilalui dengan sepeda motor dan jalan menuju akses Pulau Santen sudah di paving dibawah paving tersebut dibuatlah gorong-gorong untuk jalannya air bersih hanya saja penggandaan air bersih masih harus ditingkatkan lagi.

Keempat, Dinas UMKM berperan dalam memberikan bantuan dan fasilitasi untuk masyarakat usia produktif maupun non produktif hal ini dapat terlihat dari semua rumah di dekat Pulau Santen yang membuka usaha warung dan yang boleh membuka usaha warung hanya warga setempat di Pulau Santen tidak boleh warga lain. Kelima, Dinas Perikanan berperan dalam pemberdayaan nelayan dan kelompok usaha bersama warga dalam hal ini Dinas Perikanan dan Kelautan Provinsi memberikan bantuan 170 set fish apartemen yang diserahkan kepada Dinas Perikanan dan Pangan Kabupaten Banyuwangi kepada kelompok nelayan bintang timur adanya fish apartemen ini diharapkan nanti akan menjadi daya tarik sendiri di pantai Pusan (Pulau Santen). Keenam, Dinas Pengairan berperan dalam pembangunan tangkis untuk menjaga kebersihan muara sungai. Ketujuh, Dinas Lingkungan Hidup berperan dalam peningkatan kualitas lingkungan dan kebersihan meskipun sudah ada pekerja lepas dari Dinas Lingkungan Hidup yang datang untuk membersihkan sampah di pantai syariah Pulau Santen, tetapi tetap sampah menjadi masalah di Pulau Santen Tersebut. Wisata tersebut masih terkesan sangat kotor sehingga pada tanggal 09 Desember 2017 Forum Banyuwangi Sehat mengadakan acara Coastal Clean Up di Pantai Syariah tersebut. ${ }^{12}$

Namun dari beberapa peran SKPD yang sudah di paparkan di atas ada yang belum bisa terealisasi diantaranya sebagai berikut: Pertama, Tokoh agama yang berperan mendampingi masyarakat setempat dalam program penataan dan pengelolaan Pulau Santen. Peran tokoh agama ini juga yang masih belum optimal. Kedua, Dinas Pendidikan berperan dalam peningkatan kualitas SDM lewat formal dan Informal dalam hal ini Dinas Pendidikan sudah memberikan izin operasional Pendidikan Anak Usia Dini (PAUD) Al-Kharomah dengan kegiatan belajar mengajar dari hari senin hingga hari kamis jumlah siswa kurang lebih ada 20 siswa khususnya anak anak dari kelurahan Karangrejo. Untuk

\footnotetext{
${ }^{12}$ Susanti, Nawal Ika.
} 
melaksanakan Kegiatan Belajar Mengajar (KBM) siswa tersebut melaksanakan di Balai Nelayan yang ada di kawasan Pulau Santen sebut. Paud Al- Kharomah ini masih belum memiliki gedung sendiri sehingga masih membutuhkan perhatian lebih dari Dinas Pendidikan Kabupaten Banyuwangi.

Ketiga, Dinas Pariwisata berperan dalam penguatan konsep wisata dan promosi berdasarkan hasil wawancara dengan koordinator lapangan yaitu pak Rangga mengatakan bahwa "saya kesulitan dalam melakukan promosi-promosi untuk menarik wisatawan yang sesuai dengan konsep wisata syariah itu sendiri" hal ini di karenakan kurangnya penguatan konsep wisata syariah dari Dinas Pariwisata dengan kata lain kurangnya sosialisasi terkait penguatan konsep wisata syariah dan bentuk-bentuk promosi yang sesuai dengan konsep wisata syariah sehingga banyak wisatawan yang salah persepsi dengan konsep wisata syariah ini. Keempat, Dinas Perumahan dan Pemukiman berperan dalam penataan kawasan kumuh dan rintisan homestay oleh warga homestay yang berada di lokasi Pulau Santen masih minim, hanya ditemui satu homestay di kawasan wisata pantai syariah (Pulau Santen) ini. Kelima, Dinas Pemuda dan Olahraga berperan dalam pengembangan olahraga pantai untuk saat ini olahraga pantai yang ada di Pulau Santen yang ada hanya olahraga air kano, hanya saja olahraga tersebut belum dilengkapi dengan baju pelampung jadi olahraga kano hanya dapat dinikmati oleh wisatawan yang bisa berenang. ${ }^{13}$

Dapat disimpulkan bahwa konsep penataan dan pengelolaan pantai syariah ini masih terkesan buru-buru karena disiapkan tidak lebih kurang dari 1 bulan sebelum launching pantai syariah dengan fasilitas seadanya meski konsep ini sudah ada sejak lama namun sosialisasi yang dilakukan oleh Pemkab untuk mengkoordinasikan peran dari SKPD (Satuan Kerja Perangakat Daerah) dan elemen masyarakat untuk penataan Pulau Santen ini masih sangat kurang. Selain konsep awal penataan Pulau Santen sebagai wisata syariah, hal lain yang tidak kalah penting untuk diluruskan kembali adalah tentang keterkaitan Pulau Santen sebagai tempat bekas lokalisasi Pakem Banyuwangi yang telah ditutup pada tahun 2013. Berita ini meresahkan warga setempat dengan adanya kabar yang termuat di media massa baik online maupun cetak dan semua pemberitaan tersebut menyebutkan bahwa Pulau Santen berada di daerah ekslokalisasi Pakem yang terkenal di Banyuwangi. ${ }^{14}$

\footnotetext{
13 Susanti, Nawal Ika.

${ }^{14}$ Susanti, Nawal Ika.
} 
Menurut Bapak Parman, pernyataan tersebut tidak benar dimana lokasi Pulau Santen dan Eks Lokalisasi Pakem Banyuwangi terletak di antara dua kelurahan yang berbeda. ${ }^{15}$ Adapun menurut Lintang Yuniasih, ${ }^{16}$ salah satu warga sekitar kelurahan Pakis yang juga menjadi pendukung dengan adanya wisata syariah di kelurahan Karangrejo.

\section{Persepsi Masyarakat terhadap Pantai Syariah (Pulau Santen)}

Data lapangan menunjukkan bahwa sebagian besar masyarakat memiliki respon yang positif dengan nilai $75 \%$. Adapun pemaparannya sebagai berikut Pertama, masyarakat yang bertempat tinggal di sekitar lokasi wisata syariah sudah mengetahui apa yang dimaksud dengan wisata syariah di Pulau Santen dengan jumlah responden masyarakat sebesar $70 \%$, sisanya mengaku belum sepenuhnya mengerti tentang wisata syariah. Hasil wawancara lanjutan menunjukkan bahwa alasan responden yang mengatakan masih belum mengetahui pengertian dan adanya wisata syariah dikarenakan Sumber Daya Manusia (SDM) yang masih rendah dan hampir semua jawaban responden mengatakan asing dengan istilah wisata syariah dikarenakan menurut mereka, wisata syariah yang mereka ketahui adalah tempat ziarah wali 9 atau para maqom waliyulloh.

Kedua, masyarakat Banyuwangi mengetahui dan memahami bagaimana konsep penerapan wisata syariah di Pulau Santen sebesar 55\% dari seluruh responden dengan kata lain lebih banyak masyarakat setempat yang belum mengetahui penerapan konsep wisata syariah di Pulau Santen. Dari hasil wawancara beberapa responden yang mengatakan belum memahami konsep wisata syariah ini disebabkan kurangnya sosialisasi dari SKPD kepada masyarakat setempat sebelum launching Pulau Santen menjadi wisata syariah.

Ketiga, Masyarakat setempat sudah mengetahui tujuan dari penataan dan pengelolaan Pulau Santen sebagai wisata syariah sebesar 80\%. Pada awalnya responden mengaku belum mengetahui tujuan dari penataan dan pengelolaan Pulau Santen sebagai pantai syariah, namun dari waktu ke waktu sebagian besar responden mengaku mengetahui tujuan dari penataan dan pengelolaan Pulau Santen sebagai pantai syariah pengetahuan ini tidak lain karena ikut

\footnotetext{
15 Wawancara dengan Parman, warga yang bertempat tinggal di dekat lokasi wisata syariah, Desember 2018.

16 Wawancara dengan Lintang Yuniasih, Masyarakat yang bertempat tinggal di dusun pakis kabupaten Banyuwangi, Desember 2018.
} 
berperannya SKPD dalam mensosialisasikan konsep dari wisata syariah Pulau Santen dan juga tujuannya. ${ }^{17}$

\section{Sikap Masyarakat terhadap Pantai Syariah (Pulau Santen)}

Sikap masyarakat tehadap penataan dan pengelolaan Pulau Santen sebagai wisata syariah dapat diukur melalui penilaian dari masyarakat, penerimaan dari masyarakat, dan sikap dari masyarakat yang mengharapkan adanya wisata syariah tersebut. Menurut Nur halimah ${ }^{18}$ sikap masyarakat sekitar terhadap pantai syariah Pulau Santen memiliki respon yang positif dengan nilai 80\% pemaparan yang dapat diambil sebagai berikut:

Pertama, masyarakat Pulau Santen sebagian besar setuju dengan pengelolaan Pulau Santen menjadi pantai syariah sebesar $80 \%$ responden menyetujui jika Pulau Santen dikembangkan menjadi pantai syariah sedangkan 20\% responden bersikap netral dan tidak setuju Pulau Santen dikembangkan sebagai wisata syariah. Kedua, masyarakat setempat menyukai konsep yang dikembangkan pemerintahan dengan menjadikan Pulau Santen sebagai wisata Syariah di Banyuwangi seluruh responden dengan jumlah 15 orang yang ada di kelurahan Karangrejo menerima konsep yang dikembangkan oleh pemerintah hal ini terbukti dari keterlibatan masyarakat dalam mengikuti setiap kegiatan pertemuan di balai nelayan yang dilakukan oleh SKPD terkait dengan pengembangan Pulau Santen sebagai Wisata Syariah di Banyuwangi.

Ketiga, penilaian masyarakat terhadap penerapan konsep wisata syariah yang ada di Pulau Santen dikatakan baik dilihat dari $70 \%$ responden memberikan nilai rentang antara 7 hingga 8 dalam penerapan konsep syariah di Pulau Santen dikarenakan konsep syariah di Pulau Santen masih belum terpenuhi secara maksimal. Mengingat masih banyak yang harus dilakukan oleh pemerintahan Kabupaten Banyuwangi untuk memaksimalkan potensi yang ada di Pulau Santen sehingga dapat dikatakan bahwa sampai saat ini Pulau Santen masih dalam tahap pengembangan wisata syariah. Keempat, masyarakat setempat menolak isu yang beredar di media sosial baik media cetak maupun yang media online terkait dengan pemberitaan bahwa Pulau Santen merupakan bekas lokalisasi Pakem Banyuwangi karena pada kenyataannya lokasi Pulau Santen

\footnotetext{
${ }^{17}$ Lintang Yuniasih.

18 Wawancara dengan Nur Halimah, Pedagang menetap di area Pulau Santen (wisata syariah), Desember 2018.
} 
dengan lokalisasi Pakem sudah berbeda kelurahan seluruh responden tidak menyetujui dengan adanya berita tersebut. ${ }^{19}$

\section{Partisipasi Masyarakat terhadap Adanya Pantai Syariah (Pulau Santen)}

Partisipasi masyarakat dapat diukur melalui masyarakat yang menikmati, melaksanakan, memelihara, Agus Hisyam Abdullah $^{20}$ menilai bagaimana partisipasi masyarakat terhadap berdirinya wisata syariah Pulau Santen tersebu. Partisipasi masyarakat terhadap pantai syariah Pulau Santen memiliki respon yang positif dengan nilai $85 \%$. Pemaparan yang dapat diambil sebagai berikut:

Pertama, Masyarakat setempat terlibat langsung dalam sosialisasi yang diadakan oleh pemerintah Kabupaten Banyuwangi sebesar 70\% dari responden dari hasil wawancara beberapa responden maka dapat dikatakan sosialisasi yang dilakukan oleh Pemerintahan Kabupaten Banyuwangi mendapatkan partisipasi yang baik dari masyarakat setempat. Kedua, Masyarakat setempat aktif dalam kegiatan yang menunjang dalam pengembangan Pulau Santen sebagai pariwisata syariah sebesar $90 \%$ responden mengakui terlibat aktif dalam setiap kegiatan yang di lakukan SKPD hal ini dapat dilihat dari sistem gotong royong antara SKPD dengan masyarakat setempat untuk menerapkan konsep wisata syariah di Pulau Santen sistem gotong royong ini pun sesuai dengan konsep awal Bupati Anas dalam mengembangkan wisata syariah dengan melibatkan seluruh SKPD dengan masyarakat setempat.

Ketiga, Masyarakat setempat ikut serta dalam pengambilan keputusan tentang pengembangan Pulau Santen sebagai Wisata Syariah sebesar 60\% beberapa responden mengaku ikut serta dalam pengambilan keputusan bersama dengan SKPD yang bertanggung jawab di setiap kegiatan salah satu pengambilan keputusan yang melibatkan masyarakat setempat adalah tentang pembuatan sumur bor di beberapa titik di Pulau Santen tokoh masyarakat mengambil keputusan untuk tidak membuat sumur bor di beberapa titik dikarenakan air di Pulau Santen merupakan jenis air payau jadi daripada membuat sumur bor yang hasilnya nanti tetep air payau daripada air tawar, maka tokoh masyarakat memutuskan untuk menolak pembuatan sumur bor tersebut, sehingga pemerintah mencari solusi dengan menyalurkan air bersih ke masyarakat setempat melalui pipa di bawah jembatan penghubung.

\footnotetext{
${ }^{19}$ Nur Halimah.

${ }^{20}$ Wawancara dengan Agus Hisyam Abdullah, Aggota karang taruna di Kelurahan Karang Rejo, Desember 2018.
} 
Keempat, masyarakat setempat aktif dalam mengemukakan pendapat di setiap kegiatan yang menunjang dalam mengembangkan Pulau Santen sebagai Wisata Syariah sebesar $90 \%$ dari responden menyatakan aktif dalam mengemukakan pendapatnya beberapa pendapat dari masyarakat setempat antara lain tentang kebersihan dari Pulau Santen masyarakat memberi pendapat untuk memberi kantong plastik kepada setiap pengunjung Pulau Santen pemberian kantong plastik ini bertujuan agar pengunjung membawa sendiri sampahnya dan membuang sampah di tempat yang telah disediakan oleh pengelola Wisata Syariah Pulau Santen. ${ }^{21}$

\section{Dampak Pantai Syariah bagi Masyarakat Kelurahan Karang Rejo.}

Dalam penelitian ini lebih difokuskan dampak dalam bidang ekonomi pendidikan dan sosial budaya berikut ini penjabaran dampak dari wisata pantai syariah Pulau Santen yang ditemukan ketika observasi di lapangan menurut Bapak Surahman. ${ }^{22}$ Dampak wisata syariah dalam bidang perekonomian hususnya berdampak positif bagi masyarakat sekitar lokasi yang ikut andil untuk mengembangkan wisata tersebut lebih khususnya bagi wisata pantai syariah beberapa pemaparan yang diberiakan bapak Surahman sebagai berikut:

Pertama, menambah pendapatan masyarakat setempat pengeluaran dari pengunjung secara langsung maupun tidak langsung merupakan sumber pendapatan yang diharapkan dari beberapa organisasi beberapa perusahaan maupun masyarakat setempat yang melakukan usaha di bidang pariwisata banyaknya jumlah pengunjung yang berwisata merupakan pasar bagi produk lokal. Kedua, meningkatnya pendapatan pemerintahan Kabupaten Banyuwangi dari sektor pariwisata namun karena Pulau Santen launching pada tahun 2017 sebagai wisata syariah maka masih perlu perhatian ekstra dari Pemkab dalam hal pengelolaan dan pengembangannya.

Ketiga, mengurangi pengangguran dan memperluas lapangan pekerjaan bagi masyarakat setempat di Pulau Santen karena masyarakat sekitar masih banyak yang menganggur terutama para pemuda dan ibu rumah tangga para pemuda dijadikan sebagi pengelola lapangan dalam tahap pengembangan Pulau Santen sebagai pantai syariah dan para ibu rumah tangga banyak yang membuka warung di sepanjang pantai Syariah. Keempat, Masyarakat setempat dapat menggunakan fasilitas yang ada di Pulau Santen pada awalnya hanya ada

\footnotetext{
${ }^{21}$ Agus Hisyam Abdullah.

22 Wawancara dengan Surahman, Pengelola Pantai syariah di Pulau Santen, Desember 2018.
} 
satu tempat ibadah di Pulau Santen dan itupun kondisinya kurang memadai semenjak Pulau Santen dijadikan Wisata Syariah maka tempat ibadah yang kurang memadai itu direnovasi oleh pemerintah dan dapat digunakan oleh warga setempat selain tempat ibadah yang ada fasilitas lain yang dapat digunakan oleh masyarakat setempat adalah fish apartemen, fish apartemen ini digunakan oleh masyarakat sebagai tempat perkembangbiakan ikan selain itu fish apartemen memberikan daya tarik wisata bawah laut di Pulau Santen. ${ }^{23}$

\section{Simpulan}

Berdasarkan pembahasan diatas maka dapat ditarik kesimpulan bahwa dalam penerapan konsep wisata syariah di Pulau Santen belum optimal meskipun belum optimal respon masyarakat terhadap wisata pantai syariah memiliki respon yang positif baik dari segi persepsi sikap maupun partisipasi masyarakat begitu juga dari wisatawan yang berkunjung memiliki persepsi yang bernilai positif terhadap wisata syariah yang ada di Pulau Santen. Berdasarkan hasil kesimpulan diatas maka ada beberapa saran yang dapat diberikan oleh peneliti yaitu:

Pertama, pemerintahan Kabupaten Banyuwangi lebih memperhatikan perkembangan Pulau Santen sebagai wisata pantai syariah karena ini merupakan salah satu aset wisata yang kelak dapat menjadi wisata unggulan di Banyuwangi. Kedua, pemerintahan Kabupaten Banyuwangi untuk dapat mensinergikan antara SKPD agar pengembangan pantai syariah Pulau Santen lebih maksimal karena berdasarkan hasil temuan peneliti dilapangan terjadi kurangnya komunikasi antar SKPD yang berkepentingan dalam pengembangan Pulau Santen sebagai wisata pantai syariah. Ketiga, pemerintahan Kabupaten Banyuwangi memfasilitasi semua kegiatan yang dapat meningkatan potensi yang sudah ada di Pulau Santen. Keempat, Berdasarkan hasil respon masyarakat baik masyarakat setempat maupun pengunjung Pulau Santen masih harus terus dikembangakan lagi dengan memaksimalkan semua potensi yang ada di Pulau Santen tanpa merusak ekosistem yang sudah terbentuk di Pulau Santen, seperti manggrove, savana dan juga terumbu karang

\footnotetext{
${ }^{23}$ Surahman.
} 


\section{Daftar Pustaka}

Ahmad, Zamri. "A Study of Performance of the KLSE Syariah Index". Malaysian Management Journal, 6 (1\&2), (2002) School of Management Universiti Sains Malaysia

al-Asy'ari, M. Khoirul Hadi. Kajian Potensi dan Strategi Pengembangan Wisata Pantai Syariah. Jurnal MD 3 (1) (2017) Prodi Perbankan Syari’ah, Fakultas Ekonomi dan Bisnis Islam, IAIN Jember

Badan Koordinasi Penanaman Modal (BKPM). Potensi dan Peluang Investasi Kabupaten Banyuwangi. Jakarta: PT Buanatama DimensiConsultants, 2013.

Dinas Kabupaten Banyuwangi. Kabupaten Banyuwangi dalam Angka. Banyuwangi: BPS, 2002.

Masful, Mila Falma. "Pariwisata Syariah: Suatu Konsep Kepercayaan Nilai Budaya Lokal Di Daerah Pedalaman Pilubang, Payakumbuh, Sumatera Barat". Jurnal The Messenger 9 (1), (2018) FIKOM Universitas Sahid Jakarta

Hadi, Firdausia. 2017. Kajian Potensi dan Strategi Pengembangan Wisata Pantai Syariah. Jurnal Md. 3 (1) (2017) Prodi Perbankan Syari'ah, Fakultas Ekonomi dan Bisnis Islam, IAIN Jember

Nur, Siti Khayisatu Zahro, "Pengembangan Sector Pariwisata Melalui Program Festival Halal Kuliner. Jurnal Et-Tijarie, 5 (2) (2018) Universitas Muhammadiyah, Jember.

Permadi, Lalu Adi. "Persepsi dan Sikap Masyarakat Terhadap Rencana Dikembangkannya Wisata Halal (Halal Touris di Nusa Tenggara Barat)". Jurnal Amwaluna. 2 (1) (2018) Fakultas Ekonomi dan Bisnis Universitas Mataram Jl. Majapahit 62 Mataram

Puspita, Dewa. "Analisis Pengembangan Pulau Santen dengan Konsep Syariah" Jurnal Administrasi Binis. 55 (1) (2018) Fakultas Ilmu Administrasi Universitas Brawijaya

Sunaryo, Bambang. Kebijakan Pembangunan Destinasi Pariwisata: Konsep dan Aplikasinya di Indonesia. Yogyakarta: Gava Media, 2013.

Susanti, Nawal Ika. Respon Masyarakat Terhadap Pantai Syariah Pulau Santen di Kelurahan Karangrejo Banyuwangi. Jumal Istiqro. 4 (1) (2018). Institut Agama IslamDarussalam Blokagung

Hernanda, Dedy Wahyu. "Pemberdayaan Masyarakat dalam Pengembangan Wisata Syariah (Halal Tourism) di Pulau Santen Banyuwangi. Prosiding 
Seminar dan Call For Paper e-ISSN (2595-1064) Fakultas Ilmu Administrasi Universitas Brawijaya, Malang, 2017.

\section{Wawancara}

Wawancara dengan Agus Hisyam Abdulla, Anggota Karang Taruna di Kelurahan Karang Rejo, pada tanggal 22 Desember 2018.

Wawancara dengan Parman, warga yang bertempat tinggal di dekat lokasi wisata syariah, pada tanggal 21 Desember 2018.

Wawancara dengan Surahman, pengelola pantai syariah di Pulau Santen pada tanggal 23 Desember 2018.

Wawancara dengan Lintang Yuniasih, masyarakat yang bertempat tinggal di Dusun Pakis Kabupaten Banyuwangi, pada tanggal 21 Desember 2018.

Wawancara dengan Nur Halimah, pedagang menetap di area Pulau santen (wisata syariah), pada tanggal 22 Desember 2018.

\section{Blog}

http://www.banyuwangibagus.com/-2017/03/pulau-santen-jadi-wisatapantaisyariah-per-tama-di-indonesia.html) diakases pada tanggal 18122018

https://blog.ub.ac.id/taniafristylia/2013/02/21/pengaruh-lingkunganterhadap-pemasaran diakses pada tanggal 13122018

https://www.goodnewsfromindonesia.id/2017/09/09/pantai-pulau-santenjadi-wisata-syariah-pertama-di-indonesia diakses pada tanggal 13122018 
